
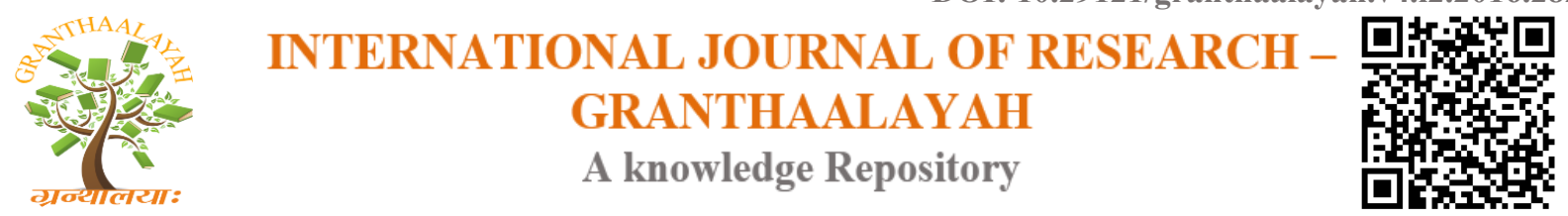

Management

\title{
THE RELATIONSHIP BETWEEN CUSTOMER SATISFACTION AND INTERNAL SERVICE QUALITY FROM AN INTERNAL MARKETING PERSPECTIVE AND AN APPLICATION IN THE BANKING SECTOR
}

\author{
Özlen Onurlu ${ }^{* 1}$, Suna Karataş ${ }^{2}$ \\ ${ }^{* 1}$ Department of Business Administration, Marmara University, TURKEY \\ ${ }^{2}$ Department of Business Administration, Bahcesehir University, TURKEY
}

\begin{abstract}
In a highly competitive environment, the meeting of customer demands and expectations in an effective way is highly crucial for companies that want to have a competitive advantage and to keep on existing in the long run. The main objective of companies is making profit in a sustainable way and this is possible by assuring customer satisfaction. The quality of the services that companies offer their customers is closely related with the performance of the employees. This has made it necessary that marketing activities for employee satisfaction be developed prior to customer satisfaction. Feeling more motivated, workers start working more eagerly as a result of these marketing activities which are called internal marketing. So, companies make their profitability sustainable by means of keeping their customers satisfied and loyal.

The aim of this paper is to investigate the relationship between internal marketing activities applied to employees and employee motivations.
\end{abstract}

Keywords:

Internal marketing, internal service quality, internal customer satisfaction, external customer satisfaction, banking sector.

Cite This Article: Özlen Onurlu, and Suna Karataş, "THE RELATIONSHIP BETWEEN CUSTOMER SATISFACTION AND INTERNAL SERVICE QUALITY FROM AN INTERNAL MARKETING PERSPECTIVE AND AN APPLICATION IN THE BANKING SECTOR” International Journal of Research - Granthaalayah, Vol. 4, No. 2 (2016): 159-178.

\section{INTRODUCTION}

With rising competition, technological developments and globalization, the main objective of companies is to be profitable, make their profitability sustainable and goes on existing. Within this conception, in order to be able to get through this competitive environment, the main thing that they need to concentrate on is keeping their present and new customers satisfied and making them loyal. In order to assure the sustainability of their customers' satisfaction and the realisation of their goals for the future, companies firstly need to detect their customers' wants, needs, and 
expectations. The detection of the wants, needs, and expectations of customers isn't enough for the sustainability of the existence of a company. The main thing is the effective presentation of the products and services that are being offered and effective presentation is closely related with employee performance. In this vein, in order for customer satisfaction to be assured, the main thing a company needs to focus on is the assuring of employee satisfaction and helping them work with full performance by means of increasing their motivations. This in turn is possible through the employment of effective "internal marketing" activities and getting internal service quality higher [1]. This way, employees can be satisfied, their willingness to quit their jobs can be minimized and they will work in a more devoted and enthusiastic way. Because of that, companies need to cherish their employees, i.e. humans, improve them and meet their needs and help them form cultural values that they can share among each other and this in turn should be reflected towards internal service quality [2].

In this vein, discussion in this study is about the internal marketing activities that need to be employed for the enhancement of the satisfaction level of the employees which have a great impact on the enhancement of customer satisfaction. The motivation increasing factors for employees will be taken into consideration.

\section{THE SERVICE CONCEPT AND EXTRA COMPONENTS OF SERVICES MARKETING}

\section{The Service Concept and Its Significance}

Services are elements that are put on the market with the intention of satisfying people's needs; they need no ownership, they are abstract and they bring utility and fulfillment [3].

The percentage that the service sector takes within the entire economy of a country and its contribution to the economy is seen as a sign of that country's development. The reason for that is the fact that when the life standards of societies rise, demand for companies in the service sector rises too [4].

The basic principles regarding the marketing of a tangible product and a service are the same. However, there are qualities that make services different from products. These are intangibility, inseparability, heterogeneity and perishability [6].

These qualities of services make it difficult for the preparation and application of an efficient marketing program. Because of that, services marketing need certain extra components [7].

\section{The Extra Components of Services Marketing}

Services marketing involves 3 extra components. These are external marketing, internal marketing and interactive (reciprocal, conversational) marketing [4].

External marketing consists of the supply of the product, price, promotion and place activities to the customers [8].

Internal marketing is based on the idea that in order for companies to have satisfied customers, they need to have satisfied employees first and this in turn can be achieved by integrating the principles of marketing to the work design and employee motivation by means of treating employees the same way as customers [9]. 
Interactive marketing refers to the service providers' having a good relationship with the customers, having the ability and competence in this area [10].

\section{Services marketing triangle}

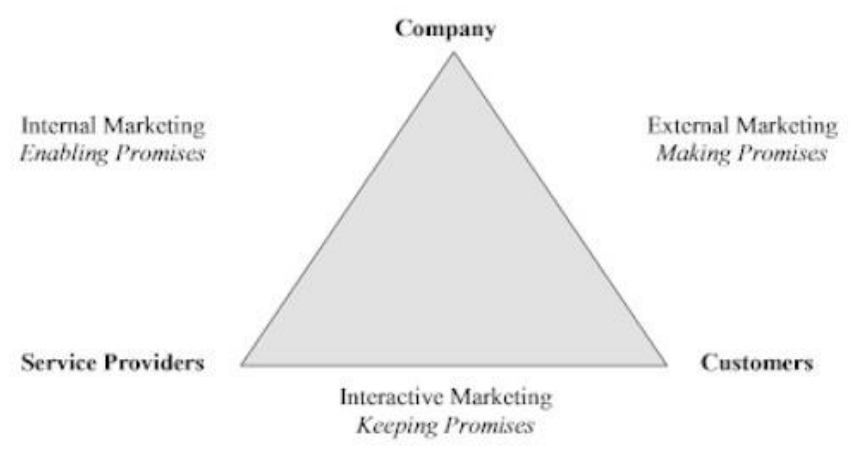

Source : [11]

In services marketing, these 3 sub components have a big part in the reinforcement of the service provided to the customer and the relationship with the customer. Within this context, in order for the promises to be kept first of all internal marketing and the services process should be empowered [11].

\section{The Internal Marketing Concept and Its Significance}

The internal marketing concept stresses the importance of employees in services marketing and has appeared in the marketing literature since the 1980s [5]. The internal marketing concept that is usually studied together with services marketing in the marketing literature, has been evaluated by Berry in 1981 for the first time. Having named bank employees as internal customers, Berry has introduced the internal marketing concept with the aim of stressing the effects internal customer satisfaction has on external customers. The internal marketing concept has afterwards been used in many areas, primarily in the management literature [12]. The internal marketing concept separates a company's customers as internal and external. Employees are given the same amount of respect as the customers anda re called internal customers. Internal marketing is about the application of the marketing concept inside the company as it is applied to the external customers [5]. Internal marketing is a management philosophy which is about the attraction of employees towards the company and making them loyal to the company.

\section{THE RELATION BETWEEN SERVICE QUALITY AND CUSTOMER SATISFACTION}

\section{The Service Quality Concept and its Significance}

Service quality occurs as a result of customers' expectations of a service and the comparison of the performances of services. That is, service quality is seen as a measure of the extent to which the expectations of customers can be met. The concept of service quality has an internal and an external service quality perspective [13].

Hizmet kalitesi kavramı iç hizmet kalitesi ve dış hizmet kalitesi olarak ele alınmaktadır. 
Internal service quality is a process whereby the personnel, managers and the company as a whole are all involved. Internal service quality is formed as a result of the interaction of these elements with each other. In internal service quality, the management type of the company the qualifications of the employees, their education levels, education opportunities, communication, responsibility, authority, team collaboration and the 'we' feeling are the determining components. Internal service quality, the detection and fulfillment of the problems, demans and requirements of the employees by means of providing an open internal communication [2]. So, companies should treat their employees working in all departments, from the personnel at the bottom of the hierarchy to the top management, as customers and provide internal services to them, maket hem happy economically as well as socially and psychologically [14].

External service quality in its broadest sense means providing a superior or perfect service in order to meet customer expectations and demands. Another definition of external service quality puts it as the ability of a company to meet or transcend customer needs. The important point here is that quality here refers to the 'perceived' quality by customers. Companies are striving to reach competitive superiorities by creating satisfactory and ideal quality.

\section{The Relation Between Internal Service Quality and Customer Satisfaction}

Today, especially in the service sector, employees are in direct and intense communication with customers, and so employee performance is virtually seen as an investment to the relationship process. The effect of the relationship between the employees and customers on employee and customer satisfaction can be explained with "Balance Theory" and "Emotional Transmission Theory". According to the balance theory, the relationship is said to be in balance when there is accordance in the attitudes and behaviours of the parties in a relationship between two people, wheras the relationship is said to be unbalance in that relationship when there is no accordance in their attitudes and behaviours. In this case, the attachment and the feeling of satisfaction that employees feel towards their work and company will create satisfaction and create a flow of emotions. Emotional transmission refers to the transposition of emotions among people during an interaction or people effecting each other's emotions. Emotions are usually not controlled by employees in a conscious way, and in case a negative situation (such as work stress) is reflected upon the employee as dissatisfaction, customers perceive the dissatisfaction on the face and in the words of the employee and with emotional transmission's influence they too feel the dissatisfaction [15].

\section{CUSTOMER, CUSTOMER SATISFACTION AND ITS SIGNIFICANCE}

In the literature, the customer concept has been studied in the following two groups: "internal customer" and "external customer".

Internal customers, are defined as the employees ranging from the authorised officer at the top to the new personnel working for the same company, meeting the expectations of the final consumers of a product or service and realizing the work and tasks related with each other [17]. Internal customers are the employees of a company and have a significant place in the development of the production and service process efficiency of a company [16]. Internal customers are all of a company's employees that contribute to the service provision process either directly or indirectly [14]. 
External customers are people who want to get maximum benefit from a product or service with the condition that they are of good quality. In other words they are the ones that consume the product and services that internal customers produce [16]. External customers consist of everyone who is not a member of the company but is aware of the products and services that a company produces and has the potential of buying them. That is, they are the ones who get affected by the product or services that are being produced [17].

In this study, internal service quality from the perspective of internal marketing is studied centrally, so points about internal customer satisfaction have been mainly dwelled upon, and external customers shortly mentioned.

\section{Müşteri Memnuniyeti Kavramı ve Önemi}

Customer satisfaction involves the comparison between the product (s)he chooses and the one that (s)he gives up. The product that is given up is the product that the customer considers to buy but doesn't choose to do so. If the chosen product is superior to the product that is given up customer satisfaction occurs. In the reverse case, that is if the chosen product has performed less than the product that has been given up, or is inferior in quality, then customer dissatisfaction occurs. As the continuity of a customer's satisfaction of a product is secured his/her demand for that product is going to continue, and so the effect of customer satisfaction on renewed purchases is great. In case of dissatisfaction though, the probability of renewed purchases will drop. [15].

Customer satisfaction that makes up the basic foundation blocks of companies is mandatory for companies' sustainability. For a company, internal customer satisfaction is as important as the satisfaction of external customers. So, the concept of customer satisfaction is important for both internal and external customers [17].

Internal customer satisfaction satisfaction is the situation when there is no difference between employee expectations from a product, service or relationship and the meeting of those expectations for that particular product, service or relationship. [17]. Internal customer satisfaction happens when the employee feels pleased about his/her job, the qualities of the job and the expectations and wants of the employee match each other [15].

For the sustainability of a company, the most accurate source of information is the employee, who is together with the customers during the marketing of product and services. In the management process, employees working in sublevels of a company have the most balanced knowledge rather than the top management per se. Employees are customers at the same time and the quality of the work that they do might depend on the satisfaction or dissatisfaction they might get related to the dimensions such as working hours, wages, promotion and perception of the fulfillment of these values The significance of internal customer satisfaction is great in terms of the increases in their productivity. That's because the existence of unhappy, unsatisfied employees makes it difficult for a company to continue its existence. In case internal customer satisfaction can be increased, external customer satisfaction will increase too. So, the happiness of employees unified with the company is one of the first things that companies should take into consideration. [17].

External customer satisfaction is a customer based important structure that occurs with a customer evaluation that has at its basis the comparison between customers' (who are not the 
member of a company) previous experiences and how the provided services are being perceived. External customer satisfaction also affects the later buying behaviours of customers as well. Together with that, satisfaction is a result of the service experience and customer satisfaction or dissatisfaction is related with the quality of the product or service. [15].

\section{FACTORS AFFECTING CUSTOMER SATISFACTION}

One of the main objectives of companies in the past was to find customers who would buy their product or services. However, this objective is not enough in our day. The cost of finding new customers being higher than than the cost of keeping the existant ones; not only finding the customers but also keeping them is part of the realization of the objectives. With the advance of technology and increasing competition, customer satisfaction and loyalty is becoming harder. Customers are becoming more conscious and choose what they want, knowing exactly what it is that they want [16]. In this context, companies need both internal and external customer support. The happiness of external customers is secured by the happiness of the internal ones. In this vein, there are a lot of factors effecting internal and external customer satisfaction.

\section{FACTORS AFFECTING INTERNAL CUSTOMER SATISFACTION}

Internal customer satisfaction, which refers to the delight and happiness that employees get out of their work life, occurs through their perception of the work environment and their work as satisfier and this in turn is related with a lot of factors [15].

Wages and rewards Wage is defined as the sum of the material values that an employee gets as the result of the work that the employee undertakes. For the employee, the wage and material opportunities that (s)he gets as a compensation fort he work (s)he does is very important. [17]. The wage that employees get effects the purchasing power and so it has a decisive effect on their quality of life. Employees form their attitudes towards the company about wage because wage also has an effect on the social status. Rewards are seen as a way of delivering a "thank you" message to an employee who performs well [15]. Rewards are used as a tool for holding qualified employees at the company, making them satisfied and motivated and so developing employees' behaviours and performances [18]. If a company is expecting a difference in employee behaviour, it is crucial that it changes its reward structure according to the expecations of the employees. [19].

Job safety Precautions taken about the work environment while doing the required task, the opportunities offered to them (such as life and accident insurances, retirement) are significant for making them feel secure. [15].

Communication is the process that takes place with the aim of securing the information flow, unification, motivation and decision making in the production and management process that is needed for a company to reach its aims and objectives [20]. One thing affecting internal customer satisfaction very much is the communication that an employee has with his/her collegues and managers, it is necessary for the strengthening of the feeling of beloning and his/her feeling well about being in that environment [15]. 
Physical working conditions The working environment and conditions of employees should be arranged in such a way that the employees don't get harmed and their mental and physical activities don't get effected in a bad way [17]. Voices, light, noises, tools might help the employees with their work, but they might just as well make their work more difficult. The securing of the physical working environment where the employees can get the highest efficiency levels affects internal customer satisfaction in a positive way. [15].

Education With the internal and external education about subjects such as work and behaviour provided to the personnel by the institution can raise the expected utility margin [17]. Work satisfaction of the personnel and therfore their loyalty to the institution is raised after education, where employees feel themselves valued and invested upon [1].

Carrier opportunuties Career consists of all the work that an employee does in all his/her work life. The forming of the career plans of employees and securing their professional advancements should be seen as an investment which will give results in the future. Career satisfaction aims at internal customer satisfaction by means of getting a successful result in developing new competencies for employees' career objectives, earnings, and progress [17].

Qualities of the job The love employees have for the job and the delight that it gives to them is important for the satisfaction it creates. If the qualities that the job necessitates make it possible for the employees to do their work as well as improve themselves or if it necessitates variety instead of uniformity and if they are appreciated, this contributes to internal customer satisfaction [15].

Communications with collegues Having successful and respectful collegues at work increases internal customer satisfaction. Close friendships, collaborations and solidarity forms a positive working environment as well as making a positive effect on customers [1].

Organization structure The lack of a hyerarchic and vertical communication system in an organization, and the existence of a system that employees are part of is effective in internal customer satisfaction. In an organization where employees have difficulty in expressing themselves, being misunderstood, feeling invaluable, dissatisfaction occurs.

Organization size The size of an organization too is crucial for for internal customer satisfaction Components of employee satisfaction work in a different way in small or big companies and effect processes. Bigger companies getting a higher market share, their being more important for brand recognition and development makes it more probable that employees are proud of the company that they belong to. [15].

Other factors Main components of internal customer satisfaction have been explained in a detailed way in previous headings. On the other hand, factors such as the securing of for work leave rights with or without payment, making use of insurance rights in an effective way, the choice of the employee of the month, the arrangement of parties and joyful celebrations for employees are evaluated as motivating components for internal customer satisfaction [21]. 


\section{FACTORS AFFECTING EXTERNAL CUSTOMER SATISFACTION}

Factors affecting external customer satisfaction can be spread to a wide array. In this array, special company objectives that are thought of as not concerning the customer may take place as well. Because of that, the arrangement of all of the factors in external customer satisfaction seems impossible [22]. In this vein, the factors effecting external customer satisfaction can be said to be quality, expectations, perceived performance and price [23].

\section{MATERIALS AND METHODS}

\section{THE RELATION BETWEEN INTERNAL SERVICE QUALITY AND CUSTOMER SATISFACTION FROM AN INTERNAL MARKETING PERSPECTIVE IN THE BANKING INDUSTRY}

The Topic and Objective of the Study: Considering that the importance of internal marketing quality provided to the employees is high in customer satisfaction, the aim of this study is to investigate the satisfaction level of the employees working in the banking sector of the internal services quality, considering the factors affecting internal customer satisfaction and is to find out if there is a the relation between their satisfaction levels and demographical characteristics (gender, age, education level, tenure). The main topic of this study is the identification of the satisfaction level employees feel as a result of the internal marketing activities applied by the institution that they work for, especially in the services sector, where employees are highly important for customer satisfaction. This study is based on the banking sector.

The Scope and Limitations of the Study: The domain of the study consists of the bank which has the highest profit among the top 5 banks in Turkey, which have received the highest profit for the first 6 months of 2015. As it is impossible to reach the head quarters and branches of the bank timewise as well as in terms of cost, only the headquarters and branches in İstanbul were included in the study. Convenience sampling method was used in the study and the participants of the study were the 165 personnel of the relevant bank.

The Method of the Study and the Data Collection Method: The study is descriptive and data have been gathered through the survey method which is a widely used method. The survey method has been used in the study doe to the fact that the questions can reach greater masses when compared with other research methods and it is more advantageous in terms of time and cost. A questionnaire form of 28 statements has been prepared. The questionnaire form consisted of 3 sections. The first part of the questionnaire consisted of 5 questions determining the demographics of the participants. The second part of the questionnaire consists of 22 question statements on a 5 point Likert scale for determining if the internal marketing strategies that the institution applies to its employees for increasing employee satisfaction is sufficient or not. The statements were prepared as a result of a literature survey considering the factors seen to be effective in employee satisfaction. In the third section of the questionnaire, the employees were asked to state the different factors other than the ones already stated in the questionnaire, if there are any, that may increase their motivations in the institution that they are working for. When the questionnaire form was being prepared, it has been considered that the questions and statements are clear, straightforward, and plain enough not to be boring for the participants. 


\section{The Hypothesis of the Study and the Analysis of the Data}

Reliability Analysis: Reliability analysis is made in order to measure if the questionnaire items have been perceived by the participants in the same way or not, in other words, if the data disperse randomly. If the questionnaire data disperse randomly, the questionnaire results can be said to be reliable. In this case, there is no need for leaving out a question from the questionnaire.

In order to detect if the survey questions are reliable or not, Cronbach Alpha value is being used. The evaluation criteria used in commenting on the Cronbach Alpha value is as follows; if 0,00 a 0.40 , the scale is not reliable;

0.40 a 0.60 , the reliability of the scale is low;

0.60 a 0.80 , the scale is quite reliable;

0.80 a 1.00 , the scale is highly reliable.

A reliability analysis has been made on the survey questions and the Cronbach's Alpha value is found out to be 0,90 . Therefore, we can say that the scale is highly reliable.

The Testing of the Hypothesis Used in the Study: The hypothesis used in the study have been tested through the Ki square test on a 95\% reliability level. If the $\mathrm{p}$ value resulting from the $\mathrm{Ki}$ square test is lower than 0,05 then the hypothesis $\mathrm{H} 0$ is rejected. That is, it is concluded that there is a relationship between variables. In this vein, the results of the hypothesis testings are as follows:

a) H0: There is no relationship between the income of the employees and their satisfaction levels with respect to the wage they receive from the institution they work for.

H1: There is a relationship between the income of the employees and their satisfaction levels with respect to the wage they receive from the institution they work for.

According to the $\mathrm{Ki}$ square test done on a $95 \%$ reliability level, significance value has been found as $\mathrm{p}=0,265$. As $\mathrm{p}>0,05$, the H0 hypothesis is accepted. There is no relationship between the income of the employees and their satisfaction levels with respect to the wage they receive from the institution they work for.

b) H0: There is no relationship between the employees' experiences and their satisfaction levels of the relationship they have with their managers.

H1: There is a relationship between the employees' experiences and their satisfaction levels of the relationship they have with their managers.

According to the $\mathrm{Ki}$ square test done on a $95 \%$ reliability level, significance value has been found as $\mathrm{p}=0,011$. As $\mathrm{p}<0,05$, the $\mathrm{H} 0$ hypothesis is rejected. There is a relationship between the employees' experiences and their satisfaction levels of the relationship they have with their managers.

c) H0: There is no relationship between employees' income and their satisfaction levels of career planning.

H1: There is a relationship between employees' income and their satisfaction levels of career planning. 
According to the $\mathrm{Ki}$ square test done on a $95 \%$ reliability level, significance value has been found as $\mathrm{p}=0,007$. As $\mathrm{p}<0,05$, the $\mathrm{H} 0$ hypothesis is rejected. There is a relationship between employees' income and their satisfaction levels of career planning.

d) H0: There is no relationship between the income of the employees and the satisfaction levels they get from the work that they do.

H1: There is no relationship between the income of the employees and the satisfaction levels they get from the work that they do.

According to the $\mathrm{Ki}$ square test done on a $95 \%$ reliability level, significance value has been found as $\mathrm{p}=0,774$. As $\mathrm{p}>0,05$; the $\mathrm{H} 0$ hypothesis is accepted. There is no relationship between the income of the employees and the satisfaction levels they get from the work that they do.

e) H0: There is no relationship between the employee's gender and the satisfaction levels they get from the work that they do.

H1: There is a relationship between the employee's gender and the satisfaction levels they get from the work that they do.

According to the $\mathrm{Ki}$ square test done on a $95 \%$ reliability level, significance value has been found as $\mathrm{p}=0,003$. As $\mathrm{p}<0,05$; the $\mathrm{H} 0$ hypothesis is rejected. There is a relationship between the employee's gender and the satisfaction levels they get from the work that they do.

f) H0: There is no relationship between the employees' marital status and the satisfaction levels they get from the work that they do.

H1: There is a relationship between the employees' marital status and the satisfaction levels they get from the work that they do.

According to the $\mathrm{Ki}$ square test done on a $95 \%$ reliability level, significance value has been found as $\mathrm{p}=0,001$. As $\mathrm{p}<0,05$; the $\mathrm{H} 0$ hypothesis is rejected. There is a relationship between the employees' marital status and the satisfaction levels they get from the work that they do.

g) H0: There is no relationship between tenure and the satisfaction levels they get from the work that they do.

H1: There is a relationship between tenure and the satisfaction levels they get from the work that they do.

According to the $\mathrm{Ki}$ square test done on a $95 \%$ reliability level, significance value has been found as $\mathrm{p}=0,009$. As $\mathrm{p}<0,05$; the $\mathrm{H} 0$ hypothesis is rejected. There is a relationship between tenure and the satisfaction levels they get from the work that they do.

h) H0: There is no relationship between the employees' age and their satisfaction levels from the social and cultural activities.

H1: There is a relationship between the employees' age and their satisfaction levels from the social and cultural activities.

According to the $\mathrm{Ki}$ square test done on a $95 \%$ reliability level, significance value has been found as $\mathrm{p}=0,984$. As $\mathrm{p}<0,05$; the $\mathrm{H} 0$ hypothesis is accepted. There is no relationship between the employees' age and their satisfaction levels from the social and cultural activities. 


\section{RESULTS AND DISCUSSIONS}

In our day when it is easier to reach customers as a result of globalization and technological advances, it is crucial that companies, differentiating themselves from their competitors, secure customer satisfaction and loyalty. Securing customer satisfaction is not only about the selling of products and services, but it's also about the way services are offered to customers, that is service quality. The main component determining the quality of the service provided to the customers, are the employees who provide the service. Employee performance is to a great extent responsible for the service quality that employees provide, and they are also called internal customers. In this content, as is mentioned in the second part of this study, in order for companies to be profitable in a sustainable way, the foremost thing that they need to prioritize is the securing the satisfaction employees get out of their work and the of the facilities that their work brings, by means of employing internal marketing activities. This, in turn, is possible through a high level of internal service quality as mentioned in the third part of the study. In this study, it has been observed how the employees of a public bank perceive internal service quality as a result of the internal marketing activities under the extent of the factors mentioned in the fourth part of the study, which are effective in achieving of employee satisfaction, which in turn is of great importance for achieving customer satisfaction.

In the study, the survey method has been employed as the data gathering method and response to our questionnaire has been received from 165 participants. Five point Likert scale has been used in the study, and the participants have been asked to what degree they agree with the statements in the questionnaire.

When the demographic qualities of the participants are observed, we can see that $56 \%$ of them are women, $56 \%$ are married, $70 \%$ belong to the $28-35$ age group, $36 \%$ earn between $3001-4000$ TL, tenure of $53 \%$ of them is betwen $0-5$ years.

According to the results of the survey, $66 \%$ of the employees of the institution under consideration don't find the wage they earn satisfying when compared with the work that they undertake and $46,1 \%$ of them don't find extra income and rewards satisfying. In this case,

Having a great role in the securing of customer satisfaction, the institution which wants to increase the motivation of its employees and make them work in a more enthusiastic way can go through an amendment in wages and increase rewards through extra earnings. Fifty five point 2 percent, which makes up most of the respondents, have expressed their satisfaction saying that information is delivered on time in the institution.

Fifty two point one percent of the participants have stated that they are happy with the relationship they have with their managers, $42,4 \%$ have expressed their satisfaction with their managers' dealing with employee problems and providing feedback. According to the survey results, $61,8 \%$ of those who have participated in this survey stated that they are satisfied with the physical conditions in their work environment (heating, cleaning, illumination, etc.), 49,7\% have stated that they can reach necessary resourses easily.

When the satisfaction levels relating to the career planning that the institution makes are observed, $64,2 \%$ of the participants have stated that the career planning that the institution makes 
is not motivating. There is a high level of dissatisfaction about career planning. In this situation, the institution needs to consider the education of employees as an investment that will have good results in the future and motivate them in this way.

When the satisfaction levels regarding the promotion practices in the institution are inspected, a percentage as high as 70,3\% think that the promotion practices are not done fairly in the institution.

When the satisfaction levels of participants with regard to the delight they get out of their work is considered, it can be seen that 50,9\% of them do their work with delight.

When the satisfaction levels regarding the respect employees have towards each other and their collaboration is considered, it can be seen that $52,1 \%$ of the employees think that employees have respect for each other, $44,8 \%$ have expressed their satisfaction because of the collaboration among employees. Fifty five point eight percent think that the institution they are working for is an ideal institution when compared with other institutions in the same sector.

When the satisfaction levels related with social and cultural activites are questioned, we see that $72,7 \%$ of the employees think that the social and cultural activities of the institution is insufficient. In the banking sector, where stress and pressure rates are higher in comparison to other sectors, the engagement of employees in social and cultural activities has an important place in the minimization of the feeling of pressure. As is seen from the survey results, one of the components that employees feel less satisfied with in the institution is the insufficiency of the social and cultural activities. The institution can increase the motivations of is employees by means of preparing occasions in which the employees can spend time with one another other than during the working hours.

When the satisfaction levels of the employees in the evaluation of their performances is investigated, we can see that $60 \%$ of them think that the performance evaluation made is not fair and transparent. A fair performance evaluation is a significant component of the enhancement of employee performance. The sharing of the results of the performance evaluations that the institution does to its employees results in the employees' trying to improve themselves in those areas where they find themselves deficient and so make it possible for them to become a more efficient employee. Therefore, the relevant bank should do a fair and transparent performance evaluation in order to increase employee motivations.

When the work security measures taken by the institution and the satisfaction levels from the opportunities such as health insurance, severence pay are investigated, 56,4\% have stated their satisfaction from security measures, and 52,7\% think that the opportunities such as health insurance, severance pay are at a satisfactory level in meeting their needs.

As a result of the testing of the hypothesis used in the study with a Chi square analysis, no relationship has been found between employee income and the satisfaction level they get out $\mathrm{f}$ the wage they receive from the institution. At the same time, there is found to be no relationship between employees' income and the level of satisfaction they get from their work. There is found no relationship between the age of employees and the level of satisfaction they get from the 
social and cultural activities. When tested, a relationship has been found between the satisfaction levels employees have from the relationship they have with their bosses and the tenure of the employees. A relationship has been found in the satisfaction levels employees get from career planning and their income. Besides, a relationship has been found between the gender of the employees, their marital status and tenure and the level of satisfaction they get from the work that they do.

As a result, when internal service quality is evaluated by considering the 165 participants, the participants have stated that they are satisfied with 13 of the 22 total statements. In this way, more efficient internal marketing activities should ne applied for success in employee satisfaction. If wages, amendments in extra earnings and rewards, managers dealing closer with employee problems, a more efficient career planning, fairer promotions, the arrangement of social and cultural activities that increase motivation, managers appreciating the work that is being done and their attitudes and behaviours being more motivating is secured, the relevant bank can have a very successful performance in terms of employee satisfaction. So, by means of the employees with high performances, customer satisfaction and loyalty can increase and that may increase the profitability of the institution.

\section{APPENDINX}

Table 1: Descriptive Statistics

\begin{tabular}{|l|l|l|}
\hline Questions & Mean & $\begin{array}{l}\text { Standart } \\
\text { Deviation }\end{array}$ \\
\hline $\begin{array}{l}\text { The wage I receive at work is satisfactory when compared with the work I } \\
\text { undertake }\end{array}$ & 2,28 & 1,02 \\
\hline $\begin{array}{l}\text { The extra profit and rewards (extra payment, premium etc.) that my } \\
\text { company provides me are enough in order to increase my motivation }\end{array}$ & 2,71 & 1,03 \\
\hline $\begin{array}{l}\text { In the company I work, all notifications (notices, messages) are made on } \\
\text { time. }\end{array}$ & 3,35 & 1,02 \\
\hline In the company I work, I can communicate with my managers easily. & 3,43 & 0,96 \\
\hline $\begin{array}{l}\text { The management team (upper management and others) deals with all my } \\
\text { problems and gives feedback. }\end{array}$ & 2,67 & 1,03 \\
\hline $\begin{array}{l}\text { The physical conditions (heating, cleaning, illumination) at work are at a } \\
\text { satisfactory level. }\end{array}$ & 3,44 & 1,09 \\
\hline $\begin{array}{l}\text { The company I work for makes it possible for me to easily reach necessary } \\
\text { equipment and resources. }\end{array}$ & 3,30 & 0,96 \\
\hline $\begin{array}{l}\text { The career planning that the company I work for makes for me satisfies my } \\
\text { needs and increases my motivation. }\end{array}$ & 2,24 & 0,93 \\
\hline In the company I work for, employees promote in a fair way. & 2,05 & 0,96 \\
\hline $\begin{array}{l}\text { The work that I undertake at the company I work makes it possible for me } \\
\text { to develop myself. }\end{array}$ & 2,98 & 1,06 \\
\hline In the company I work for, I enjoy my job and I love it. & 3,36 & 1,09 \\
\hline In the company I work for, employees have respect for one another. & 3,36 & 0,96 \\
\hline There is collaboration among employees in the company I work for. & 3,22 & 0,93 \\
\hline $\begin{array}{l}\text { I think that the company I work for is one of the most ideal institutions to } \\
\text { work for, in its sector. }\end{array}$ & 3,44 & 1,01 \\
\hline
\end{tabular}




\begin{tabular}{|l|l|l|}
\hline $\begin{array}{l}\text { The company I work for lets me utilize from (all) paid and unpaid leave of } \\
\text { absence rights on my demand without bringing about problems. }\end{array}$ & 3,54 & 1,02 \\
\hline $\begin{array}{l}\text { The company I work for is concerned with its employees by means of } \\
\text { arranging motivation increasing social and cultural activities. }\end{array}$ & 2,02 & 0,92 \\
\hline $\begin{array}{l}\text { A fair and transparent performance evaluation is made in the company I } \\
\text { work for. }\end{array}$ & 2,26 & 0,93 \\
\hline $\begin{array}{l}\text { The company I work for gives enough education for the development of } \\
\text { abilities. }\end{array}$ & 2,88 & 0,94 \\
\hline $\begin{array}{l}\text { In the company I work for, my manager encourages me by appreciating the } \\
\text { work I do. }\end{array}$ & 2,85 & 1,03 \\
\hline $\begin{array}{l}\text { In the company I work for, the attitudes and behaviours of the management } \\
\text { are motivating. }\end{array}$ & 2,70 & 1,00 \\
\hline $\begin{array}{l}\text { In the company I work for, the security measures (fire, flooding, electric } \\
\text { leakage, theft etc.) undertaken are at a satisfactory level in terms of } \\
\text { motivating me. }\end{array}$ & 3,41 & 0,99 \\
\hline $\begin{array}{l}\text { In the company I work for, facilities such as health insurance and } \\
\text { severence pay meet my needs sufficiently. }\end{array}$ & 3,38 & 1,10 \\
\hline
\end{tabular}

When table 1 is observed, the following data from the descriptive statistics are received.

When the descriptive statistics are observed, the first three statements with the highest average of satisfaction level of participants are "The company I work for lets me utilize from (all) paid and unpaid leave of absence rights on my demand without bringing about problems", "I think that the company I work for is one of the most ideal institutions to work for, in its sector" and "the physical conditions (heating, cleaning, illumination) at work are at a satisfactory level" respectively. The three statements with the lowest average of satisfaction level are "the company I work for is concerned with its employees by means of arranging motivation increasing social and cultural activities", "in the company I work for, employees promote in a fair way", and "the career planning that the company I work for makes for me satisfies my needs and increases my motivation".

Table 2: Frequency and percentage distributions of the satisfaction levels for each statement according to the research findings

To the statement "the wage I receive at work is satisfactory when compared with the work I undertake", $66,7 \%$ of the participants expressed their opinions as I don't agree/I don't agree at all; and $16,4 \%$ as I agree/I totally agree.

To the statement "The extra profit and rewards (extra payment, premium etc.) that my company provides me are enough in order to increase my motivation", most of the participants making up $46,1 \%$ expressed their opinions as I don't agree/I don't agree at all; and 25,5\% as I agree/I totally agree.

To the statement "In the company I work, all notifications (notices, messages) are made on time", 20,6\% of the participants expressed their opinions as I don't agree/I don't agree at all; and $55,2 \%$ as I agree/I totally agree. 
To the statement "In the company I work, I can communicate with my managers easily", 16,4 \% of the participants expressed their opinions as I don't agree/I don't agree at all; and 52,1\% as I agree/I totally agree.

To the statement "the management team (upper management and others) deals with all my problems and gives feedback", 42,4\% of the participants which makes up the majority, expressed their opinions as I don't agree/I don't agree at all; and $24,2 \%$ as I agree/I totally agree.

To the statement "the physical conditions (heating, cleaning, illumination) at work are at a satisfactory level", $20 \%$ of the participants expressed their opinions as I don't agree/I don't agree at all; and $61,8 \%$ as I agree/I totally agree.

To the statement "the company I work for makes it possible for me to easily reach necessary equipment and resources", $20 \%$ of the participants expressed their opinions as I don't agree/I don't agree at all; and 49,7\% as I agree/I totally agree.

To the statement "the career planning that the company I work for makes for me satisfies my needs and increases my motivation", $64,2 \%$ of the participants expressed their opinions as I don't agree/I don't agree at all; and $11,5 \%$ as I agree/I totally agree.

To the statement "in the company I work for, employees promote in a fair way", 70,3\% of the participants expressed their opinions as I don't agree/I don't agree at all; and 11,5\% as I agree/I totally agree.

To the statement "the work that I undertake at the company I work makes it possible for me to develop myself', 34,5\% of the participants expressed their opinions as I don't agree/I don't agree at all; and $37,6 \%$ as I agree/I totally agree.

To the statement "in the company I work for, I enjoy my job and I love it", $18,2 \%$ of the participants expressed their opinions as I don't agree/I don't agree at all; and 50,9\% as I agree/I totally agree.

To the statement "in the company I work for, employees have respect for one another", $20 \%$ of the participants expressed their opinions as I don't agree/I don't agree at all; and 52,1\% as I agree/I totally agree.

To the statement "there is collaboration among employees in the company I work for", $23 \%$ of the participants expressed their opinions as I don't agree/I don't agree at all; and $44,8 \%$ as I agree/I totally agree.

To the statement "I think that the company I work for is one of the most ideal institutions to work for, in its sector, $17 \%$ of the participants expressed their opinions as I don't agree/I don't agree at all; and $55,8 \%$ as I agree/I totally agree.

To the statement "the company I work for lets me utilize from (all) paid and unpaid leave of absence rights on my demand without bringing about problems", $18,8 \%$ of the participants expressed their opinions as I don't agree/I don't agree at all; and $66,1 \%$ as I agree/I totally agree. 
To the statement "the company I work for is concerned with its employees by means of arranging motivation increasing social and cultural activities", $72,7 \%$ of the participants expressed their opinions as I don't agree/I don't agree at all; and 8,5\% as I agree/I totally agree.

To the statement "a fair and transparent performance evaluation is made in the company I work for", $60 \%$ of the participants expressed their opinions as I don't agree/I don't agree at all; and $9,1 \%$ as I agree/I totally agree.

To the statement "The company I work for gives enough education for the development of abilities", 33,9\% of the participants expressed their opinions as I don't agree/I don't agree at all; and $28,5 \%$ as I agree/I totally agree.

To the statement "in the company I work for, my manager encourages me by appreciating the work I do", 35,2\% of the participants expressed their opinions as I don't agree/I don't agree at all; and $31,5 \%$ as I agree/I totally agree.

To the statement "in the company I work for, the attitudes and behaviours of the management are motivating, 39,4\% of the participants expressed their opinions as I don't agree/I don't agree at all; and $21,8 \%$ as I agree/I totally agree.

To the statement "in the company I work for, the security measures (fire, flooding, electric leakage, theft etc.) undertaken are at a satisfactory level in terms of motivating me", 16,4\% of the participants expressed their opinions as I don't agree/I don't agree at all; and 56,4\% as I agree/I totally agree.

To the statement "in the company I work for, facilities such as health insurance and severence pay meet my needs sufficiently", $19,4 \%$ of the participants expressed their opinions as I don't agree/I don't agree at all; and 52,7\% as I agree/I totally agree.

\begin{tabular}{|l|l|l|l|l|l|l|l|l|l|l|l|}
\hline Qestions & \multicolumn{2}{|l|}{ I totally agree } & \multicolumn{2}{l|}{ I agree } & \multicolumn{2}{l|}{$\begin{array}{l}\text { Neither agree } \\
\text { nor disagree }\end{array}$} & \multicolumn{2}{|l|}{ I don't agree } & \multicolumn{2}{l|}{$\begin{array}{l}\text { I don't agree at } \\
\text { all }\end{array}$} \\
\hline & Frekans & $\%$ & Frekans & $\%$ & Frekans & $\%$ & Frekans & $\%$ & Frekans & $\%$ \\
\hline $\begin{array}{l}\text { The wage I receive at work is } \\
\text { satisfactory when compared } \\
\text { with the work I undertake }\end{array}$ & 2 & $1.2 \%$ & 25 & $15.2 \%$ & 28 & $17.0 \%$ & 72 & $43.6 \%$ & 38 & $23.0 \%$ \\
\hline $\begin{array}{l}\text { The extra profit and rewards } \\
\text { (extra payment, premium etc.) } \\
\text { that my company provides me } \\
\text { are enough in order to increase } \\
\text { my motivation }\end{array}$ & 5 & $3.0 \%$ & 37 & $22.4 \%$ & 47 & $28.5 \%$ & 57 & $34.5 \%$ & 19 & $11.5 \%$ \\
\hline $\begin{array}{l}\text { In the company I work, all } \\
\text { notifications (notices, } \\
\text { messages) are made on time. }\end{array}$ & 11 & $6.7 \%$ & 80 & $48.5 \%$ & 40 & $24.2 \%$ & 23 & $13.9 \%$ & 11 & $6.7 \%$ \\
\hline $\begin{array}{l}\text { In the company I work, I can } \\
\text { communicate with my } \\
\text { managers easily. }\end{array}$ & 18 & $10.9 \%$ & 68 & $41.2 \%$ & 52 & $31.5 \%$ & 21 & $12.7 \%$ & 6 & $3.6 \%$ \\
\hline
\end{tabular}




\begin{tabular}{|c|c|c|c|c|c|c|c|c|c|c|}
\hline $\begin{array}{l}\text { The management team (upper } \\
\text { management and others) deals } \\
\text { with all my problems and gives } \\
\text { feedback. }\end{array}$ & 2 & $1.2 \%$ & 38 & $23.0 \%$ & 55 & $33.3 \%$ & 44 & $26.7 \%$ & 26 & $15.8 \%$ \\
\hline $\begin{array}{l}\text { The physical conditions } \\
\text { (heating, cleaning, illumination) } \\
\text { at work are at a satisfactory } \\
\text { level. }\end{array}$ & 17 & $10.3 \%$ & 85 & $51.5 \%$ & 30 & $18.2 \%$ & 19 & $11.5 \%$ & 14 & $8.5 \%$ \\
\hline $\begin{array}{l}\text { The company I work for makes } \\
\text { it possible for me to easily } \\
\text { reach necessary equipment and } \\
\text { resources. }\end{array}$ & 9 & $5.5 \%$ & 73 & $44.2 \%$ & 50 & $30.3 \%$ & 24 & $14.5 \%$ & 9 & $5.5 \%$ \\
\hline $\begin{array}{l}\text { The career planning that the } \\
\text { company I work for makes for } \\
\text { me satisfies my needs and } \\
\text { increases my motivation. }\end{array}$ & & & 19 & $11.5 \%$ & 40 & $24.2 \%$ & 68 & $41.2 \%$ & 38 & $23.0 \%$ \\
\hline $\begin{array}{l}\text { In the company I work for, } \\
\text { employees promote in a fair } \\
\text { way. }\end{array}$ & 1 & $0.6 \%$ & 14 & $8.5 \%$ & 34 & $20.6 \%$ & 60 & $36.4 \%$ & 56 & $33.9 \%$ \\
\hline $\begin{array}{l}\text { The work that I undertake at the } \\
\text { company I work makes it } \\
\text { possible for me to develop } \\
\text { myself. }\end{array}$ & 7 & $4.2 \%$ & 55 & $33.3 \%$ & 46 & $27.9 \%$ & 41 & $24.8 \%$ & 16 & $9.7 \%$ \\
\hline $\begin{array}{l}\text { In the company I work for, I } \\
\text { enjoy my job and I love it. }\end{array}$ & 20 & $12.1 \%$ & 64 & $38.8 \%$ & 51 & $30.9 \%$ & 15 & $9.1 \%$ & 15 & $9.1 \%$ \\
\hline $\begin{array}{l}\text { In the company I work for, } \\
\text { employees have respect for one } \\
\text { another. }\end{array}$ & 13 & $7.9 \%$ & 73 & $44.2 \%$ & 46 & $27.9 \%$ & 27 & $16.4 \%$ & 6 & $3.6 \%$ \\
\hline $\begin{array}{l}\text { There is collaboration among } \\
\text { employees in the company I } \\
\text { work for. }\end{array}$ & 7 & $4.2 \%$ & 67 & $40.6 \%$ & 53 & $32.1 \%$ & 32 & $19.4 \%$ & 6 & $3.6 \%$ \\
\hline $\begin{array}{l}\text { I think that the company I work } \\
\text { for is one of the most ideal } \\
\text { institutions to work for, in its } \\
\text { sector. }\end{array}$ & 18 & $10.9 \%$ & 74 & $44.8 \%$ & 45 & $27.3 \%$ & 19 & $11.5 \%$ & 9 & $5.5 \%$ \\
\hline $\begin{array}{l}\text { The company I work for lets me } \\
\text { utilize from (all) paid and } \\
\text { unpaid leave of absence rights } \\
\text { on my demand without bringing } \\
\text { about problems. }\end{array}$ & 19 & $11.5 \%$ & 90 & $54.5 \%$ & 25 & $15.2 \%$ & 23 & $13.9 \%$ & 8 & $4.8 \%$ \\
\hline $\begin{array}{l}\text { The company I work for is } \\
\text { concerned with its employees } \\
\text { by means of arranging } \\
\text { motivation increasing social } \\
\text { and cultural activities. }\end{array}$ & & & 14 & $8.5 \%$ & 31 & $18.8 \%$ & 65 & $39.4 \%$ & 55 & $33.3 \%$ \\
\hline $\begin{array}{l}\text { A fair and transparent } \\
\text { performance evaluation is made } \\
\text { in the company I work for. }\end{array}$ & 1 & $0.6 \%$ & 14 & $8.5 \%$ & 51 & $30.9 \%$ & 60 & $36.4 \%$ & 39 & $23.6 \%$ \\
\hline
\end{tabular}




\begin{tabular}{|l|l|l|l|l|l|l|l|l|l|l|}
$\begin{array}{l}\text { The company I work for gives } \\
\text { enough education for the } \\
\text { development of abilities. }\end{array}$ & 2 & $1.2 \%$ & 45 & $27.3 \%$ & 62 & $37.6 \%$ & 43 & $26.1 \%$ & 13 & $7.9 \%$ \\
\hline $\begin{array}{l}\text { In the company I work for, my } \\
\text { manager encourages me by } \\
\text { appreciating the work I do. }\end{array}$ & 2 & $1.2 \%$ & 50 & $30.3 \%$ & 55 & $33.3 \%$ & 37 & $22.4 \%$ & 21 & $12.7 \%$ \\
\hline $\begin{array}{l}\text { In the company I work for, the } \\
\text { attitudes and behaviours of the } \\
\text { management are motivating. }\end{array}$ & 3 & $1.8 \%$ & 33 & $20.0 \%$ & 64 & $38.8 \%$ & 41 & $24.8 \%$ & 24 & $14.5 \%$ \\
\hline $\begin{array}{l}\text { In the company I work for, the } \\
\text { security measures (fire, } \\
\text { flooding, electric leakage, theft } \\
\text { etc.) undertaken are at a } \\
\text { satisfactory level in terms of } \\
\text { motivating me. }\end{array}$ & 12 & $7.3 \%$ & 81 & $49.1 \%$ & 45 & $27.3 \%$ & 16 & $9.7 \%$ & 11 & $6.7 \%$ \\
\hline $\begin{array}{l}\text { In the company I work for, } \\
\text { facilities such as health } \\
\text { insurance and severence pay } \\
\text { meet my needs sufficiently. }\end{array}$ & 21 & $12.7 \%$ & 66 & $40.0 \%$ & 46 & $27.9 \%$ & 18 & $10.9 \%$ & 14 & $8.5 \%$ \\
\hline
\end{tabular}

When Table 2 is observed, the following findings have been found.

The employees were asked to state those other elements in the company that they thought would possibly increase their motivation levels. The participants have stated that the development of a wage politics according to duty position together with job title. Some of the participants have stated that when compared to other institutions, their institution is lagging behind and that it would be a motivating component if technology could be integrated into the work flow in a more efficient way.

Table 3: Frequencies and percentages of demographic variables

\begin{tabular}{|l|l|l|l|}
\hline Variable & Frequency & Percentage \\
\hline \multirow{4}{*}{ Gender } & Male & 72 & $44 \%$ \\
\cline { 2 - 4 } & Female & 93 & $56 \%$ \\
\hline \multirow{5}{*}{ Marial status } & Married & 93 & $56 \%$ \\
\cline { 2 - 4 } & Single & 72 & $44 \%$ \\
\hline \multirow{5}{*}{ Invoice } & $22-27$ & 32 & $19 \%$ \\
\cline { 2 - 4 } & $28-35$ & 115 & $70 \%$ \\
\cline { 2 - 4 } & $36-43$ & 9 & $5 \%$ \\
\cline { 2 - 4 } & $44-51$ & 9 & $5 \%$ \\
\cline { 2 - 4 } & 52 and more & 0 & $0 \%$ \\
\hline \multirow{5}{*}{ Working time } & $1000-2000$ & 22 & $13 \%$ \\
\cline { 2 - 4 } & $2001-3000$ & 58 & $35 \%$ \\
\cline { 2 - 4 } & $3001-4000$ & 59 & $36 \%$ \\
\cline { 2 - 4 } & $4001-5000$ & 18 & $11 \%$ \\
\cline { 2 - 4 } & 5001 and more & 8 & $5 \%$ \\
\cline { 2 - 4 } & $0-5$ years & 88 & $53 \%$ \\
\cline { 2 - 4 } & $6-11$ years & 60 & $1 \%$ \\
\cline { 2 - 4 } & $12-17$ years & 1 & $5 \%$ \\
\cline { 2 - 4 } & $18-23$ years & 9 & \\
\cline { 2 - 4 } & years more & 7 & $4 \%$ \\
\hline
\end{tabular}


The following findings can be seen when Table 3 is observed.

As a result of the findings received from the study, the frequency and percentage distributions received according to the demographic qualities of participants can are stated in Table 5.2. As can be seen in Table 1, 44\% of all 165 participants are men, and 56\% are women. As to their marital statuses, it can be seen that $56 \%$ of them are married, and $44 \%$ bachelors. Nineteen percent of the participants are between the ages 22-27, 70\% between 28-35, 5\% between 36-43, and $5 \%$ between $44-51$ years of age. When their monthly incomes are observed it can be seen that $13 \%$ of them receive an income between 1000-2000 TL, 35\% between 2001-3000 TL, 36\% between 3001-4000 TL, 11\% between 4001-5000 TL and 5\% 5001 TL and above. As to tenure, it can be seen that $53 \%$ of them have worked in the company for as long as $0-5$ years, $36 \%$ for 611 years, $1 \%$ for $12-17$ years, $5 \%$ for $18-23$ years, $4 \%$ for 24 years and more.

\section{REFERENCES}

[1] Kaya, S. \& Akyüz, A. M., 2015. Içsel pazarlama temelinde insan kaynaklarl uygulamalarının müşteri memnuniyetine etkisini belirlemeye yönelik bir araştırma. Electronic Turkish Studies, 10(2), ss. 1-30.

[2] Demirel, Y., 2009. Örgütsel bă̆lllı̆̆ın iç hizmet kalitesi üzerine etkisi: kamu ve özel sektör çalışanları üzerine bir araştırma. Dumlupınar Üniversitesi Sosyal Bilimler Dergisi, 23(23), ss. 269-281.

[3] Zengin, E. \& Erdal, A., 2000. Hizmet sektöründe toplam kalite yönetimi. Journal of Qafqaz University, 3(1), ss. 43-56.

[4] Bayuk, N., 2006. Hizmet pazarlaması ve müşteri tutma. Uluslararası Hakemli Sosyal Bilimler E-Dergisi, Eylül, (10), ss. 1-12.

[5] Öztürk, S. A., 2013. Hizmet pazarlaması. 13. Baskı. Bursa: Ekin Yayınevi.

[6] Eser, Z., 2007. Hizmetlerde pazarlama iletişimi. Ankara: Siyasal Kitabevi.

[7] Mucuk, I., 2012. Pazarlama İlkeleri. 19. Baskl. İstanbul: Türkmen Kitabevi.

[8] Javadein, S., Rayej, H., Estiri, M. \& Ghorbani, H., 2011. The role of internal marketing in creation of sustainable competitive advantages. Trends in Applied Sciences Research, 6(4), ss. 364-374.

[9] Uygun, M., Güner, E. \& Mete, S., 2013. Hizmet işletmelerinde iç müş̧teri yaklaşımının çalışanların müşteri yönlü davranış geliştirmesindeki rolü. Organizasyon ve Yönetim Bilimleri Dergisi, 5(1), ss. 129-149.

[10] Demir, H., Usta, R. \& Okan, T., 2008. Içsel pazarlamanın örgütsel bağlılık ve iş tatminine etkisi. H.Ü. Iktisadi ve İdari Bilimler Fakültesi Dergisi, 26(2), ss. 135-161.

[11] Dündar, I. P. \& Furlar, F. B. G., 2006. Içsel pazarlama ve toplam kalite yönetimi "Türkiye'deki ulusal basın işletmelerinin değerlendirilmesine yönelik bir araştırma". Bilig, (37), ss. 131-153.

[12] Candan, B. \& Çekmecelioğlu, H. G., 2009. İçsel pazarlama faaliyetlerinin örgütsel bağlılık unsurları açısından değerlendirilmesi: Bir araştırma. Yönetim, (63),ss. 41-58.

[13] Zeithaml, V. A. \& Berry, L., 1985. A conceptual model of service quality and its implication for future research (Servqual). Journal of Marketing, 49, ss. 41-50.

[14] Çoban, S., 2004. Toplam kalite yönetimi perspektifinde içsel pazarlama anlayışı. Erciyes Üniversitesi İktisadi ve İdari Bilimler Dergisi, (2), ss. 85-98. 
[15] Çakır, S. Y. \& Eğinli, A. T., 2010. Memnun çalışanlar memnun müssteriler. 1 Baskl. Ankara: Detay Yayınculı.

[16] Doğan, S. \& Kllıç, S., 2008. Iliş̧ki yönetiminde iç ve dlş müşsteri memnuniyetinin sağlanması. KMU İ̈BF Dergisi, 10(14), ss. 60-87.

[17] Pekmezci, T., Demireli, C. \& Batman, G., 2008. İ̧ müşsteri memnuniyeti: Konya un fabrikasinda bir uygulama. Dumlupınar Üniversitesi Sosyal Bilimler Dergisi, (22).

[18] Barutçugil, I., 2009. Müş̧teri ilişkileri ve satış yönetimi. 1 Baski. İstanbul: Kariyer Yayıncılık.

[19] Kaya, I., 2010. Pazarlama bi'tanedir. 1. Baskı. basım yeri bilinmiyor:Babıali Kültür Yayincilik.

[20] Işsler, D. B. \& Özdemir, Ş., 2010. Hastane işletmelerinde içsel pazarlama yaklaşımının iş tatmini ve örgütsel bağglllı üzerine etkisi: Isparta ili örneği. Hacettepe Sağllk İdaresi Dergisi, 13(2), ss. 115-142.

[21] Özdemir, G., 2014. Hizmet işletmelerinde içsel pazarlama yaklaşımı. "İş,Güç" Endüstri Iliş̧kileri ve İnsan Kaynakları Dergisi, Ocak, 16(1), ss. 54-66.

[22] Öz, M., 2011. İş hayatında başarının iki temel koşulu: tüketici davranışlarını anlayabilmek ve müşteri memnuniyetini sağlamak. Uluslararası Sosyal ve Ekonomik Bilimler Dergisi, 1(2), ss. 95-99.

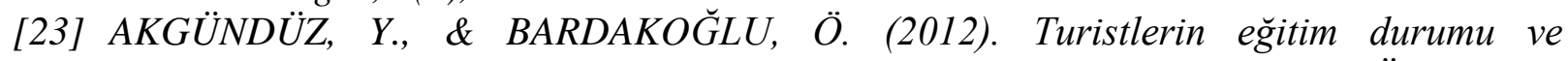
cinsiyetlerinin otel seçimine etkisi: izmir de bir araştırma. Dokuz Eylül Üniversitesi Sosyal Bilimler Enstitüsü Dergisi, 14(4), 13-29. 